\title{
The United States Congress and IMF financing, 1944-2009
}

\section{J. Lawrence Broz}

Received: 24 August 2010 /Revised: 10 February 2011 / Accepted: 11 February 2011 / Published online: 5 March 2011

(C) The Author(s) 2011. This article is published with open access at Springerlink.com

\begin{abstract}
Since 1944, United States financing of the International Monetary Fund (IMF) has been appropriated and approved in Congress by roll-call vote. If voting to increase funds to the IMF is viewed as an observable signal of "support" for the IMF, these votes provide a historical record of legislative support for the IMF in the United States. I analyze roll-call voting on IMF financing from 1944 to 2009 at both the aggregate (congressional) and the micro (legislator) levels. At the aggregate level, I show that support for the IMF has fallen over time in the House of Representatives but not in the Senate. In the micro-analysis, I use a "natural experiment" to establish that this intercameral difference is the result of the Senate's larger and more heterogeneous constituencies, as opposed to other modeled and unmodeled factors. I also find that legislator support for the IMF is shaped strongly by ideology: regardless of chamber, left-wing legislators are as much as 31 percentage points more likely to support the IMF than right-wing legislators. Yet controlling for ideology, senators are more likely to support the IMF than representatives, and representatives are more sensitive to constituency pressures than senators. I attribute these differences to chamber-specific rules governing the size of constituencies.
\end{abstract}

Keywords International Monetary Fund · IMF · United States Congress · U.S. congress $\cdot$ IMF quotas

\footnotetext{
Prepared for the 4th Annual Conference on The Political Economy of International Organizations, January 27-29, 2011, ETH Zurich and University of Zurich, Switzerland. A previous version was presented at The Political Economy of International Financial Institutions-Egon Sohmen Memorial Conference, Tübingen, Germany, June 10-13, 2010. I'm grateful to Axel Dreher, Christopher Kilby, Jeffry Frieden, and other conference participants for comments and suggestions. Daniel Maliniak provided excellent research assistance.
}

Electronic supplementary material The online version of this article (doi:10.1007/s11558-011-9108-7) contains supplementary material, which is available to authorized users.

J. L. Broz $(\bowtie)$

Department of Political Science, University of California, San Diego, La Jolla, CA, USA

e-mail: jlbroz@ucsd.edu 
JEL codes F33 $\cdot$ F42 $\cdot$ F53 $\cdot$ F55 $\cdot$ F59

\section{Introduction}

When Congress authorized United States participation in the International Monetary Fund (IMF) in 1944, it retained the "power of the purse" indefinitely, meaning that any subsequent increase in U.S. financing for the IMF would require congressional authorization and appropriation. Over the years, the IMF has requested more resources from the United States (and other member nations), to accommodate growth in the world economy and to meet crisis needs for balance of payments financing. In each instance, both houses of Congress considered and authorized the funding increases. These IMF funding authorizations, and the roll-call votes that accompanied them, are the focus of this paper.

From a social science standpoint, congressional roll-call of voting on IMF financing is important because it provides an observable record of individual and aggregate support for the IMF within the United States. When an individual legislator votes in favor of increasing U.S. funding of the IMF, it signals the lawmaker's approval of the IMF and its mission-loosening the purse strings is equivalent to a vote of support for the IMF. ${ }^{1}$ Likewise, when financing bills are passed by large majorities in the House of Representatives and the Senate, it sends the message that aggregate political support for the IMF is high in the United States. By contrast, when legislators vote against IMF financing, individually or as a majority, it signals opposition to the IMF and its practices. In short, congressional financing decisions convey information about legislative support and opposition to the IMF in the United States, the nation that is the largest contributor to the IMF and its most powerful member.

I motivate my "micro" analysis of legislator voting on the IMF with a survey of aggregate legislative support for the IMF over time (where aggregate support is measured as the share of all legislators voting in favor for new IMF funding commitments). These time series reveal a stark difference across the chambers of Congress: while aggregate support for the IMF was initially high in both the House and the Senate, support has fallen steadily in the House but not the Senate. Explaining this intercameral difference is one of the goals of this paper.

The heart of the paper is a micro-analysis of individual voting decisions by legislators. An innovation over previous work is that I have assembled roll-call voting data back to the IMF's founding in 1944 (Broz 2008; Broz and Hawes 2006a, b). In addition, I have roll-call votes from both houses of Congress over this period. The longer panel dataset allows me to examine how support for the IMF has changed over time; the roll-calls from both chambers of Congress allow me to see how institutional differences across the chambers affects legislator voting.

Building on previous work, I show that legislator "ideology" is the most important influence on how legislators view the IMF, both over time and across chambers. Controlling for other factors and including roll-call fixed effects, I find that moving a

\footnotetext{
${ }^{1}$ Legislators' votes might not be straightforward manifestations of preferences in the presence of party pressure, executive influence, or vote-buying and logrolling. In the statistical analysis, I control for some of the factors that intervene between legislators' preferences and their roll call votes.
} 
Republican legislator one standard deviation to the "right" reduces her likelihood of voting in support of the IMF by 31 percentage points. ${ }^{2}$ Moving a Democrat to the right by the same increment lowers her odds of supporting the IMF by 24 percentage points. This supports the argument that legislators use ideology as a simple schema for determining positions on the IMF and its operations. Right-wing politicians tend to oppose the IMF because they see it as providing "bailouts" that insulate international investors and foreign borrowers from the risks of their actions. By contrast, left-leaning politicians tend to focus on market failures and see a positive role for the IMF in mitigating crises that result from imperfections in international financial markets. My results show that a left-leaning ideological position is an important source of legislator support for the IMF, going all the way back to the founding of the institution.

I also find micro-level evidence that senators are more supportive of the IMF than representatives. Controlling for political party and roll-call fixed effects, Senate Democrats are 10 percentage points more likely than House Democrats to support the IMF, and Senate Republicans are 17 percentage points more likely than House Republicans to favor the IMF. I attribute this to the Senate's large, statewide constituencies that encompass more cross-cutting groups and interests than House congressional districts. Larger constituencies lead the Senate to be more supportive of the IMF than the House, just as the Senate is more supportive of free trade than the House. My best evidence is drawn from a "natural experiment" that takes advantage of the fact that certain senators and representatives have identical constituencies. Due to their small populations, states such as Vermont, Delaware, South Dakota and Wyoming are apportioned just one "Representative-at-Large" to represent the entire state. To test whether larger constituencies increase support for the IMF, I compare the votes cast by representatives-at-large with the votes of senators from these same states. I find that representatives' votes on the IMF are not statistically different than the votes of senators when they have identical constituencies. This result holds when I control for the time until the next election, which is one of the important differences between the House and Senate. When senators register more support for the IMF than representatives, it is because they have larger and more diverse constituencies, rather than because they face election less frequently than representatives.

I also test the related institutional hypothesis that the House is more susceptible to pressures from constituent groups and special interests than the Senate. I find evidence that receiving more campaign contributions from money center banks, having more skilled "pro-globalization" workers in a district, and having more workers employed in export industries increase the likelihood that a representative will vote to approve new financing for the IMF. By contrast, having more workers employed in import-competing industries reduces the likelihood a representative will vote to approve money for the IMF. None of these constituency and special interest influences holds for senators, however. I find that senators are better insulated, due to their large districts, from the societal pressures that House members face when voting on the IMF.

\footnotetext{
${ }^{2}$ My measure of legislator ideology is from Poole and Rosenthal (1997), who use spatial modeling to map legislator positions on a dominate left-right dimension.
} 
The plan of the article is as follows. In Section 2, I describe the relationship between Congress and the IMF and the congressional procedures for ratifying IMF requests for more resources. I provide information on all IMF funding increases to come before Congress since 1944 and the associated congressional roll-call votes on these allocations. Section 3 contains the aggregate analysis of congressional support for the IMF, along with conjectures about the institutional sources of intercameral differences in IMF support. In Section 4, I develop and test these arguments with micro-level voting data from Congress. Section 5 provides a summary and the implications of my research.

\section{Congress and IMF Funding Increases}

The basic terms of U.S. participation in the IMF have not changed substantively from the original law: the Bretton Woods Agreements Act of 1944 (Public Law 171, 79th Congress). Congress delegated some important functions to the Executive Branch: the President appoints the U.S. Executive Director to the IMF, and the Executive Director is ordered by law to clear his or her decisions with the Secretary of the Treasury. But Congress retained final authority over certain IMF policy areas, including funding increases. Table 1 identifies the key IMF policy areas and indicates whether congressional action is required by U.S. law in each area. Quota increases for the United States, as well as supplemental loans to the IMF via the General Arrangements to Borrow (GAB)

Table 1 U.S. congressional action needed on various IMF options

Option Congressional action

Quota increase for the United Requires congressional authorization and appropriation.

States

Loans to the IMF through the Requires congressional authorization and appropriation. GAB and NAB

Sale of IMF gold

Increase Basic Votes

4th Amendment allocating SDRs

New allocation of SDRs

Reorganize Executive Board

Ad-hoc quota increase for select countries

Revise quota formula
Requires congressional authorization under most circumstances.

Requires congressional authorization (because it amends the IMF's Articles of Agreement). ${ }^{\mathrm{a}}$

Requires congressional authorization (because it amends the IMF's Articles of Agreement). ${ }^{\mathrm{a}}$

Not required if the total amount of SDRs allocated to the United States is smaller than the current U.S. quota in the Fund.

No authorization or appropriation required under most circumstances.

However, if Board reform is done through an amendment of the Articles, congressional authorization is required. ${ }^{\text {a }}$

None required (even though this may lower the U.S. voting share).

No congressional authorization or appropriation required.

\footnotetext{
${ }^{a}$ The Bretton Woods Agreements Act requires that Congress give its assent before the United States may vote for any amendment to the IMF Articles of Agreement. This table is adapted from Sanford and Weiss (2009, Table 3)
} 
and the New Arrangements to Borrow (NAB), require congressional authorization and appropriation.

"Quotas" are the capital subscriptions that member governments make to the IMF. Quotas serve as the IMF's main resource for international stabilization activities and also determine member governments' voting power - vote shares in the IMF are tied to contributions. Quotas can be increased for all members under a "General Review of Quotas," which must be conducted at least every 5 years. ${ }^{3}$ If a General Review results in the approval of a quota increase, Congress must ratify the U.S. increase. Table 2 provides a summary of all General Quota Reviews since the founding of the IMF. As indicted in Column 3, General Reviews have produced eight major quota increases since 1944. In each instance, Congress was required to approve the increase in the U.S. quota.

While quotas are its main source of financing, the IMF supplements its resources during emergencies by borrowing directly from the United States (and other industrial countries) through the GAB and the NAB. The flexibility and importance of supplemental borrowing was made evident during the recent "subprime" global financial crisis. On April 2, 2009, members of the G-20 agreed to increase the NAB by up to $\$ 500$ billion to combat the crisis. The United States committed to a $\$ 100$ billion increase to the NAB and the overall agreement was ratified by the Executive Board of the IMF on April 12, 2010. Given U.S. law, President Obama needed to secure Congressional approval for two actions: the increase of $\$ 100$ billion for U.S. participation in the expanded NAB, and an increase of $\$ 8$ billion in the U.S. quota needed to implement the April 2008 IMF quota reform package. This proved to be difficult due to opposition from what the Wall Street Journal called "an unlikely coalition of Republicans, left-wing Democrats and anti-globalization activists" (Davis and Hitt 2009, A10).

I exploit the feature of American law that requires all increases in U.S. quotas and loans to the IMF to be approved by Congress. I assume that voting to authorize more resources for the IMF is signal of support for the IMF since providing more resources to the IMF allows it to engage in more international financial operations. ${ }^{4}$ Hence, congressional voting provides an opportunity for understanding patterns of support and opposition to the IMF within the United States.

Table 3 provides summary information on the roll-call votes analyzed in this paper. The sample is limited in several ways. First, I include only votes where the IMF funding allocation is the sole or primary content, which is to say that I do not include votes on omnibus spending bills that bundle IMF funding with various unrelated expenditures. ${ }^{5}$ For example, Senate vote \#126 in the 98th Congress (1983-84)

\footnotetext{
${ }_{3}^{3}$ Article III, Section 2(a) of the IMF's Articles of Agreement provides that "the Board of Governors shall at intervals of not more than 5 years conduct a general review, and if it deems it appropriate propose an adjustment, of quotas of members."

${ }^{4}$ In the presence of logrolling, legislators' positions on the IMF would be hard to discern from their voting behavior. Suppose legislator A votes in favor of an IMF funding bill that she mildly opposes but that is strongly favored by legislator B. In exchange, legislator B votes for a farm allocation that he mildly opposes, but that is strongly favored by legislator A. In this instance, A's vote for the IMF does not accurately convey her mild opposition to the institution.

${ }^{5}$ Vote data were obtained and cross-checked from two sources: Voteview (http://voteview.com/) and Thomas (http://thomas.loc.gov). When these sources did not agree on the content of a vote, further information was obtained from the Congressional Record (http://www.gpoaccess.gov/crecord/index.html).
} 
Table 2 IMF general quota reviews

\begin{tabular}{|c|c|c|c|c|c|}
\hline 1 & 2 & 3 & 4 & 5 & 6 \\
\hline Quota review & $\begin{array}{l}\text { Date } \\
\text { adopted }\end{array}$ & $\begin{array}{l}\text { Overall quota } \\
\text { increase (percent) }\end{array}$ & $\begin{array}{l}\text { Date } \\
\text { effective }\end{array}$ & $\begin{array}{l}\text { U.S. Quota } \\
\text { (Billions, SDR) }\end{array}$ & $\begin{array}{l}\text { U.S. share of total } \\
\text { quotas (percent) }\end{array}$ \\
\hline Founding Subscription & 1944 & 100 & 1948 & 2.750 & 32.5 \\
\hline First Quinquennial & 1950 & No increase & 1950 & 2.750 & 32.0 \\
\hline Second Quinquennial & 1955 & No increase & 1955 & 2.750 & 29.6 \\
\hline $1958 / 59$ & 1959 & 60.7 & 1959 & 4.125 & 28.4 \\
\hline Third Quinquennial & 1960 & No increase & 1960 & 4.125 & 27.0 \\
\hline Fourth Quinquennial & 1965 & 30.7 & 1966 & 5.160 & 24.3 \\
\hline Fifth General & 1970 & 35.4 & 1970 & 6.700 & 23.1 \\
\hline Sixth General & 1976 & 33.6 & 1978 & 8.405 & 22.5 \\
\hline Seventh General & 1978 & 50.9 & 1980 & 12.608 & 21.2 \\
\hline Eighth General & 1983 & 47.5 & 1983 & 17.918 & 20.2 \\
\hline Ninth General & 1990 & 50 & 1992 & 26.527 & 18.8 \\
\hline Tenth General & 1995 & No increase & 1995 & 26.527 & 18.3 \\
\hline Eleventh General & 1998 & 45 & 1999 & 37.149 & 17.7 \\
\hline Twelfth General & 2003 & No increase & 2003 & 37.149 & 17.5 \\
\hline Thirteenth General & 2008 & No increase & 2008 & 37.149 & 17.1 \\
\hline Fourteenth General & ongoing & - & - & - & - \\
\hline
\end{tabular}

The IMF conducts general quota reviews about every 5 years. Quota increases comprise an equiproportional percentage increase for all members and a selective increase, which adjusts certain members' quota shares in order to align them with their relative economic size. Column 3 is the sum of the equiproportional increase and the selective increases. The 1958/59 review was the only review conducted outside the 5-year cycle. Data on quota and quota shares are from the IMF's International Financial Statistics (IFS)

was to pass S.695, the International Recovery and Financial Stability Act. While this Act included a quota increase for the IMF and new money for the GAB, it also addressed the Export-import Bank, the supervision of international banking activities, multilateral development banks, and several other areas. It would be misleading to infer that votes on this omnibus measure indicate support or opposition to the IMF since other programs were addressed as well. Thus, I restrict the sample to votes that focus exclusively on the IMF allocation; "clean" votes that capture legislator positions on the IMF and little else.

This restriction means that some IMF funding increases are not included in the analysis, or that clean votes are available for only one chamber of Congress. To help address this problem, I extend the sample to include votes on amendments to omnibus expenditure bills that specifically target the IMF allocation. Existing research shows that congressional voting on amendments is similar to voting on final passage, in terms of the influence of political party, personal ideology, and other dominant factors (Snyder and Groseclose 2000). I therefore include amendments to omnibus bills that exclusively target funding for the IMF. For example, the $\$ 108$ billion increase for the NAB in 2009 was bundled into a supplemental appropriations bill that included financing for the wars in Iraq and Afghanistan, among other things, 
as well as for the IMF. However, on May 21, 2009 the Senate voted on an amendment that isolated the IMF allocation. The amendment, proposed by rightwing Jim DeMint (Rep-SC) — an opponent of the IMF increase-would strip IMF funding from the supplemental appropriations bill. The amendment failed by a vote of 30-64 and the IMF got its money. By voting against the amendment, senators indicated they supported extending the IMF an additional $\$ 100$ billion credit via the NAB and supported increasing the U.S. quota by $\$ 8$ billion. The vote on the DeMint amendment is "clean" and therefore included in the analysis.

\section{Aggregate Support for the IMF in the House and Senate}

I begin the analysis with an aggregate indicator of congressional support for the IMF: the size of the margin voting in favor of IMF funding by chamber. When a chamber approves IMF funding increases by wide margins, it stands to reason that the IMF commands a high level of support in that chamber. By contrast, when funding increases are approved by narrow margins - or fail to be approved altogether-it signals that the chamber views the IMF less favorably. While factors other than legislators' native "support" for the IMF shape the size of these marginsinternational crises, conflicting spending priorities, budget conditions, etc.- vote margins provide a rough gauge of aggregate congressional support for the IMF, both over time and across houses of Congress.

I expect that the level of aggregate support the IMF enjoys in Congress is likely to differ systematically between chambers, due to differences in electoral institutions across the chambers. The U.S. has a bicameral legislature consisting of an upper house-the Senate-and a lower house-the House of Representatives. The 435 members of the House of Representatives serve 2-year terms and represent small districts, apportioned by population, while the 100 senators serve 6 -year terms and represent entire states. Existing research suggests that support for the IMF should be higher in the Senate than in the House, due to senators' larger constituencies. Having large districts means that senators represent heterogeneous constituencies; thus, cross-cutting pressures from interests within their districts should make them relatively less sensitive to anti-globalization and anti-IMF pressures than representatives. This "constituency size" argument is commonplace in the literature on trade policy (Baldwin 1985; Rogowski 1987; Magee et al. 1989; Keech and Pak 1995; Bailey et al. 1997; Gilligan 1997; Irwin and Kroszner 1999). In his classic paper, Rogowski $(1987,208)$ argues that it is "almost self-evident" that large districts offer insulation from particularistic pressures and therefore a more internationalist outlook. Similarly, Baldwin $(1985,16)$ asserts that "Since senators generally represent more populous and industrially diversified political units than House members, it is less likely that the proportion of workers employed in import injured industries will be so high that a senator is forced to adopt a protectionist posture." This argument can be extended to support for the IMF since the IMF is the international financial institution charged with promoting trade and global economic integration. Just as the Senate is more free trading than the House, so too should it be more supportive of the IMF. 
Figure 1 indicates that the level of support for the IMF is higher in the Senate than in the House. The vertical axis displays the share of the chamber voting in favor of new appropriations for the IMF; the year the vote occurred is shown on the horizontal axis. The figure reveals that aggregate support for the IMF has fallen steadily over time in the House but not in the Senate. In 1945, 95\% of House members registered support for the vote to fund and authorize initial U.S. participation in the IMF. By 1998, only 46\% of House members could muster support for the IMF on the clean vote identified in Table 3. This roll call took place on April 23, 1998, during the height of the Asian currency crisis when the IMF was desperate to increase its resources to deal with the spreading crisis. But the failure of the House to approve this procedural motion - which would have allowed the House and Senate to pass identical spending bills and thereby provide the IMF with $\$ 18$ billion-stalled the IMF appropriation for another 6 months. The subsequent spread of the crisis to Russia and Brazil, along with President Clinton's admonishment of congressional foot-dragging as "irresponsible," ultimately helped convince House opponents that they would be blamed if a global recession took place (Frankel and Roubini 2003, 187). But it was not until October, 1998 that the House finally approved the IMF's $\$ 18$ billion (in an omnibus supplemental spending package), and many House conservatives were still deeply skeptical about the funding increase.

The decline in House support for the IMF may reflect increasing antiglobalization sentiment during the post-war period. With small districts, representatives may have been more exposed to interest group and constituency pressures associated with increasing international economic integration. The IMF is the international institution charged with protecting world trade and payments from financial distress; it is a natural target for constituencies harmed by deepening global economic integration (Woods 2006).

One conjecture is that support for the IMF was high in the House in the early post-war period because few congressional districts faced serious import competition at that time. The war's destruction of the capital stock of the other major industrial countries and the disintegration of goods markets had left the United States running large trade surpluses: from 1945 to 1955, the U.S. trade surplus averaged an impressive $1.76 \%$ of GDP per year. ${ }^{6}$ By the early 1970 s, the boom for the tradables sector was over as post-war recovery and rapid economic growth in Europe and Japan led to surging imports and the onset of persistent U.S. trade deficits. Since 1975, the nation imported more goods and services than it exported and the trade deficit has averaged $-2.05 \%$ of GDP between 1975 and 2009. Large trade deficits, along with falling transportation costs and reduced barriers to trade, meant that more U.S. workers and firms were exposed to foreign competition-both at home and in world markets - than before. As a result, anti-globalization pressures intensified and were reflected in the House of Representatives (Destler 2005). It's possible that opposition to globalization spilled over to the IMF and reduced representatives' support for new funding increases.

Figure 2 provides suggestive evidence. The figure plots the correlation between support for the IMF in the House and the U.S. trade balance. The trade balance fits the data well $\left(R^{2}=0.72\right)$ and the correlation is highly significant $(t=4.84)$. While

\footnotetext{
${ }^{6}$ Trade balance data are from Historical Statistics of the United States (2010).
} 
Fig. 1 Aggregate support for IMF financing by chamber, 1945-2009. Notes: Observations correspond to the roll-call votes on IMF funding listed in Table 3

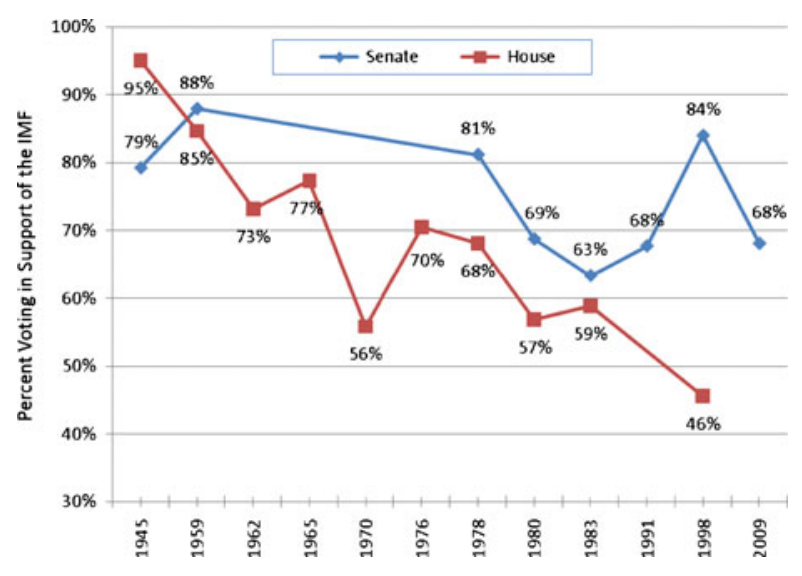

other factors may correlate with support for the IMF in the House, the trade balance seems potentially important. Global competition, as well as import surges caused by U.S. macroeconomic policies - e.g., the "strong dollar" policy of the first Reagan administration-correlate strongly with the decline in IMF support among representatives.

Aggregate support for the IMF in the Senate, however, does not fit this pattern. Figure 1 suggests that support in the upper chamber has been higher than in the House for all votes except the first one in 1945. Furthermore, Senate support is unrelated to the trade balance: the correlation is positive but not significant $(t=1.02$, $P=0.349$ ).

Greater support for the IMF in the Senate might be expected, given differences in electoral institutions. With their statewide constituencies, senators may be more insulated from anti-globalization pressures and thereby more able than representatives to take an internationalist outlook on the IMF, as they do on other foreign policy issues (Meernik and Oldmixon 2004; Cronin and Fordham 1999). If senators represent more populous and industrially diversified political units than House members, it is less likely that the proportion of workers and firms that are negatively affected by import competition will be so high that a senator is forced to adopt an anti-IMF posture. I explore this hypothesis in the micro-level analysis below.

Note that the "constituency size" argument also extends to the office of the president. With a nationwide constituency, presidents have been consistently less protectionist than Congresses (Baldwin 1985; Lohmann and O'Halloran 1994; Milner and Rosendorff 1996). According to Karol (2007, 486), "Since 1932 all presidents have indeed been more supportive of freer trade than the Congresses with which they served." Presidents have also consistently supported the IMF more strongly than the Congresses with which they served. In fact, every IMF quota increase has been supported by the president despite partisan and ideological differences across presidents. A good example of this occurred in 1983 when aggregate Senate support for IMF funding ebbed to its lowest level (63\%). The context was the IMF's Eighth General Quota Review, which coincided with the Latin American debt crisis. The debt crisis aroused strong ideological divisions in Congress over IMF funding (Boughton 2001, 867-70). The Eighth Review quota increase proposal was attacked by left-of-center legislators who saw it as a bailout 
for commercial banks that had lent imprudently to developing countries. Conversely, right-of-center politicians attacked the IMF quota increase as a bailout for indebted countries with excessive governmental intervention in their economies (Boughton 2001, 869). The ideological opposition delayed the appropriation, which led the IMF to impose a partial freeze on new lending (Bordo and James 2000, 32). The threat to the global banking system and U.S. national interests spurred President Ronald Reagan to undertake a strong personal campaign to elicit support for the appropriation. Despite his right-wing ideology, Reagan said he had "an unbreakable commitment to increased funding for the IMF" and referred to the Fund as the "linchpin of the international financial system." Reagan urged Congress to back the large quota increase to prevent an "economic nightmare that could plague generations to come" (Farnsworth 1983, 1).

While "ideology" has relatively less influence on presidential support for the IMF, it is an important source of congressional attitudes toward the IMF. ${ }^{7}$ As I have argued elsewhere, ideology provides legislators with a simple schema for evaluating policy towards the IMF, which they tend to know little about (Broz and Hawes 2006a, b). Nearly all issues and votes in Congress fall along the "left-right" dimension epitomized by the role of government in the economy (Poole and Rosenthal 1997). Funding the IMF is no different (Locke 2000). Right-wing politicians that believe in a small role for government in the domestic economy oppose the IMF because they think IMF programs distort economic incentives in the global economy. They view IMF programs as "bailouts" that insulate investors and borrowers from the risks of their actions and thereby promote greater instability in international finance. The right also opposes expansion of the government sector and they see international organizations like the IMF as particularly prone to waste and inefficiency. ${ }^{8}$ Conversely, the left focuses on market failures at both the domestic and the international levels and sees a positive role for IFIs in mitigating the economic and social costs of financial and development crises. The left also tends to be more optimistic about the operations of international organizations, and the motivations of the officials that inhabit them. ${ }^{9}$ In short, ideology provides the foundation upon which legislators evaluate the IMF.

The ideological divide on the IMF widened in 1983 when the Latin American debt crisis starkly illustrated the moral hazard problem (Smith 1984). It became wider still during the Asian currency crises when the Clinton administration approached Congress for increasing the resources of the IMF by $\$ 18$ billion (Locke 2000). By that point, the proposal was immediately and forcefully opposed by House conservatives. After a long battle, the final appropriations bill passed with a proviso that a special bipartisan commission be established to consider the future of the IMF and the other international financial institutions. The Meltzer Commission,

\footnotetext{
${ }^{7}$ While both Ronald Reagan and George W. Bush were initially susceptible to right-wing arguments against the IMF, once in office, they both supported new IMF funding proposals. See Smith (1984) and Babb (2008).

${ }^{8}$ See, for example, Dick Armey (Rep, TX), “The Moral Hazard of IMF Expansion." Remarks prepared for delivery on the House Floor, October 2, 1998. http:/www.imfsite.org/finprograms/hazard.html

9 See, for example, John J. LaFalce (Dem, NY), "The Role of the United States and the IMF in the Asian Financial Crisis," Address before the Institute for International Economics, Washington, DC, January 27, 1998. http://www.iie.com/publications/papers/paper.cfm?ResearchID=301
} 
Fig. 2 U.S. trade balance and support for the IMF in the house of representatives. Notes: The source for the trade balance data is Historical Statistics of the United States: Millennial Edition Online (2010)

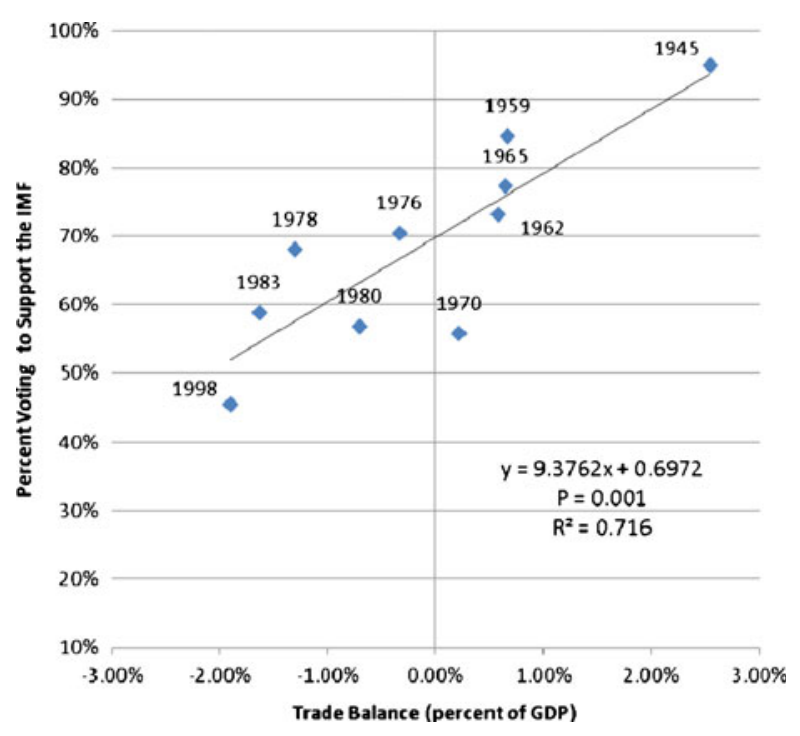

named for its chair, economics professor Allan Meltzer, produced a report in November 1998 that encapsulates the tension between the right-wing and the leftwing views of the IMF. ${ }^{10}$ While the right-wing majority on the commission emphasized how IMF programs created a moral hazard for international banks and borrowing countries alike, left-wing dissenters argued that the IMF has a necessary and important place in the world economy, due to market failures in international finance.

Spatial scaling techniques developed by Poole and Rosenthal (1997) are well established tools for estimating the ideological positions of legislators and legislatures over time (Poole 2005). The DW-NOMINATE methodology yields estimates of each member's ideal point in each Congress and allows the estimated locations to be compared across Congresses. Previous research has demonstrated that the first dimension of DW-NOMINATE locations reveal standard left-right cleavages (Poole and Rosenthal 2007). ${ }^{11}$ To investigate whether "ideology" might help explain why the Senate tends to be more supportive of the IMF than the House, Figure 3 plots the average value of the first dimension DW-NOMINATE for each house of Congress from the 79th Congress (1945-46) to the 110th Congress (200708). I am interested in the difference in the average ideology of the Senate and the House because, if ideology accounts for the higher level of support for the IMF in the upper chamber, then the Senate should be systematically more left-wing than the House. The figure does not support this conjecture as there is no clear left-wing bias in the Senate. A comparison of means test confirms that the small difference $(0.004)$

\footnotetext{
${ }^{10}$ See also Meltzer (2011).

${ }^{11}$ Because Poole and Rosenthal construct their estimates using only roll call data, DW-NOMINATE conflates two sources of legislator ideology: constituency characteristics and the personal beliefs of members. Constituents shape legislator ideology by electing members with similar beliefs_right-wing electorates tend to elect legislators who occupy right-wing positions in the NOMINATE space. Thus, DWNOMINATE incorporates both constituency and personal ideological beliefs. See Fleck and Kilby (2002) and Fordham and McKeown (2003).
} 
in average ideology between the House $(x=-0.014)$ and the Senate $(x=-0.018)$ is not statistically significant $(t=0.653)$. Average ideology does not appear to explain why the Senate is more supportive of the IMF than the House.

This preliminary investigation has revealed that average support for the IMF is higher in the Senate than in the House, and that House support has declined in correlation with the trade balance. While there is little evidence that ideological differences across chambers "explain" these intercameral differences, we cannot rule out the possibility that electoral institutions are at work. The evidence presented is consistent with the "constituency size" argument: with larger and more heterogeneous constituencies, senators are inclined to take a more internationalist (pro-IMF) outlook than representatives. With large populations, states encompass a wider variety of groups and interests than do congressional districts (which are sometimes gerrymandered to produce a single interest or dominant partisan predisposition). Due to their diverse and cross-cutting constituencies, senators might also be more insulated from the parochial pressures that representatives face during periods of high import penetration.

The aggregate evidence is merely suggestive. To evaluate these claims with greater rigor, I move to the micro-analysis of legislator voting behavior.

\section{Micro-level Analysis of Legislator Support for the IMF}

In this section, I analyze the individual voting decisions of senators and representatives on the sample of "clean" IMF funding bills to come before Congress since 1944. The aim is to build on the arguments and conclusions from the previous section, which can be restated at the micro-level:

1. The more left-wing the ideology of the individual legislator, the more likely the legislator is to vote in support of a new appropriation for the IMF.

2. Controlling for ideology and party affiliation, senators are more likely than representatives to vote for a new IMF appropriation due to their larger constituencies.

3. Representatives are more sensitive to constituency pressures than senators on matters relating to IMF financing.

The first argument reflects the fact that ideology structures almost all roll-call voting in Congress (Poole and Rosenthal 1997), including votes on the IMF (Broz and Hawes 2006a, b). The second hypothesis captures the argument that intercameral differences in the size of constituencies give senators a more internationalist outlook on IMF policy than representatives. The third hypothesis tests the claim that, due to their smaller districts, House members are more susceptible to pressures from constituents and special interests that are affected, directly or indirectly, by the IMF's international financial activities.

With respect to interest groups that are directly affected by the IMF's activities, I focus on "money center" banks. Money center banks are the nation's largest global banks. They engage in international finance and have a heavy involvement in wholesale banking with clients comprising many retail banks and global corporations. Citigroup, J. P. Morgan Chase, and Bank of America fit this description. 
Money center banks comprise a key constituency for the IMF. On the one hand, IMF financial rescues provide de facto insurance to these banks, allowing them to retain the gains from international lending while distributing losses, when they occur, to the public sector. IMF rescues are a form of insurance to these private creditors, and thus a source of moral hazard (Bulow and Rogoff 1990; Rogoff 1999). Indeed, Bird (1996) finds that the financial assistance the Fund provides to debtor countries is often used to repay loans to commercial banks. In some instances, debt service is an explicit component of IMF programs (Gould 2003). ${ }^{12}$ Demirguc-Kunt and Huizinga (1993) also find general evidence of the benefits moral hazard provides to banks by showing that unanticipated increases in U.S. financial commitments to the IMF cause the stock market capitalization of the exposed banks to increase. On the other hand, the operations of the IMF expand international opportunities for money center banks and promote policies in developing countries that are conducive to debt repayment. Thus, I expect campaign contributions from money center banks to have a positive impact on the propensity of representatives to vote in favor of increasing U.S. contributions to the IMF.

With respect to constituents that are indirectly affected by the IMF's activities, I expect House members representing districts with greater proportions of net "losers" from economic globalization to be more likely to oppose increasing the IMF's resources. This is because the IMF, by pursuing its mandate to promote the expansion, integration, and stability of the global economy, encourages globalization and its attendant domestic distributional consequences (Woods 2006; Moser and Sturm 2011).

Two models from trade theory identify the losers and winners of the IMF's pro-globalization policies: the Ricardo-Viner model and the Stolper-Samuelson model. My extension to IMF funding recognizes that the IMF's mandate to protect the world economy from financial disorder is a benefit to constituencies that gain from global economic integration and a cost to groups that suffer. From the Ricardo-Viner perspective, I thus expect House members with higher shares of constituents employed in export industries to be more receptive to IMF funding increases than members with large numbers of workers employed in import-competing industries. From the Stolper-Samuelson perspective, I expect members representing districts with greater proportions of high-skilled workers to support IFI funding increases, while representatives with greater shares of lowskilled workers in their districts will oppose these appropriations.

\subsection{Data, Models, and Results}

The dependent variable in the following regressions is the legislator's vote on IMF funding increases. The roll-calls included in these analyzes are listed in Table 3. Votes are coded $1=$ "support" for the IMF funding increase, and $0=$ opposition to the appropriation. ${ }^{13}$ The data are in panel format with the legislator-vote as the unit of

\footnotetext{
${ }^{12}$ Oatley and Yackee (2004) find that countries in which U.S. money center banks are more heavily exposed are more likely to receive support from the IMF, controlling for other correlates.

13 On the four roll calls where a "nay" vote supports the IMF appropriation, "nay"=1 and "yea"=0 (roll calls \#341, \#125, \#149, \#201).
} 


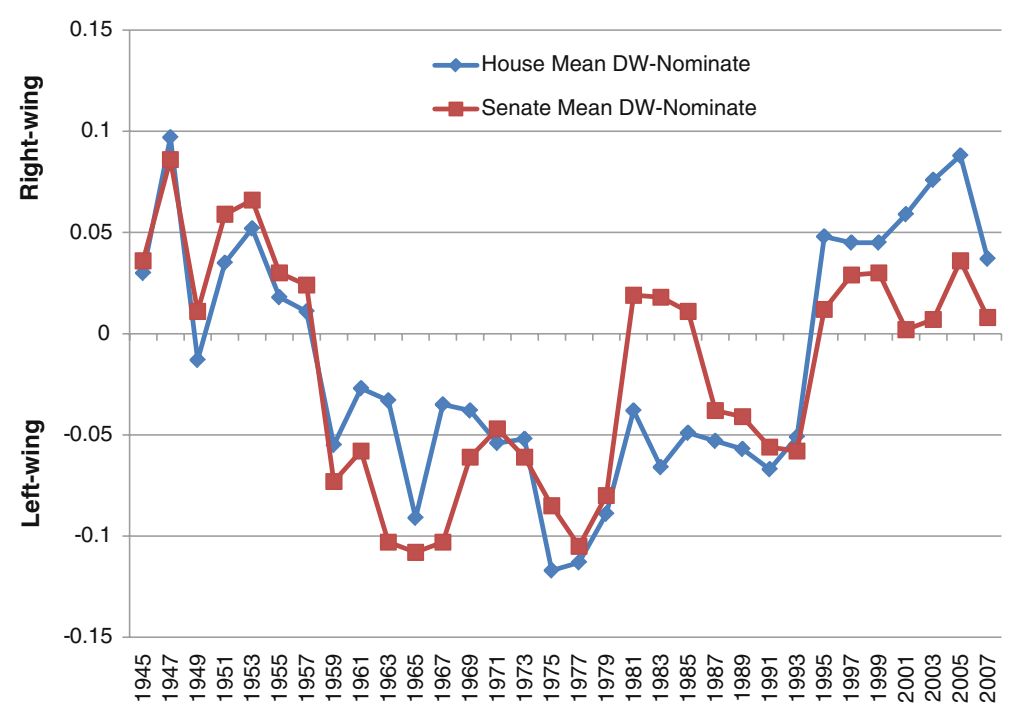

Fig. 3 Ideology of the house and senate, 1945-2008. Notes: The figure graphs the mean value of the first dimension DW-NOMINATE score by chamber. DW-NOMINATE scores are widely used measures of legislators' ideological locations over time. Scores range from -1 to 1 , with higher values denoting a more right-wing ideology. See Poole and Rosenthal (1997)

analysis. The panel specification means that I am combining roll-call votes within and across congressional sessions, which allows for a simple and compact analysis of the data. I estimate probit models with robust standard errors clustered by legislator, to deal with across-observation relationships in the error term. I include roll-call fixed effects to control for any unmodeled heterogeneity across votes and differences in the yea-nay margin over time.

Table 4 presents results related to my first two arguments. Hypothesis 1 is that legislators with more left-wing ideologies will be more likely to support IMF funding increases. I evaluate this argument using the first dimension of a legislator's DW-NOMINATE score as a proxy for "ideology." DW-NOMINATE estimates range from -1 to +1 (from most left-wing to most right-wing) and are available for all legislators in my sample of IMF financing roll-call votes (1945-2009). Given how closely the Poole-Rosenthal scores are related to political partisanship, I estimate the effect of DW-NOMINATE separately for each party. I also control for PRESIDENT'S PARTY, which is a binary variable equal to 1 if the legislator is a member of the same political party as the current president. I include this control because ideology may correlate with being of the same party as the president, which would predispose legislators to support the IMF if presidents exert executive influence on co-partisans (presidents have uniformly supported IMF funding bills when they come before Congress).

In Models 4.1 and 4.2, the negative and highly significant estimates for DWNOMINATE suggest that right-wing legislators are more likely to oppose financing the IMF than left-wing legislators. This holds for both Democrats (Model 4.1) and Republicans (Model 4.2), even taking into account whether a legislator is a member of the same political party as the president. Sharing the president's party affiliation also matters, as both Democrats and Republicans are more likely to approve new 
money for the IMF when they belong to the same party as the president, but personal ideology affects voting behavior independent of this relationship. ${ }^{14}$

To test Hypothesis 2, that legislators from the upper house are more supportive of the IMF, Models 4.3 and 4.4 adds the binary variable, SENATE, to the regressions. The coefficient estimate is positive and highly significant for both Democrats (Model 4.3) and Republicans (Model 4.4), controlling for individual ideology and party ties to the president. Model 4.5 pools Democrats and Republicans and includes roll-call vote fixed effects (not shown) to deal with unmodeled heterogeneity across votes and over time. The estimates for DW-NOMINATE and SENATE remain highly statistically significant $(z=-23.13, z=6.20$ respectively) in the proper direction.

Figure 4 provides a substantive interpretation of these probit results and a sense of the magnitude of the effects. I simulated the predicted probability of observing a vote in favor of increasing the IMF's resources, and then examined how the predicted probabilities change as the explanatory variables increase one standard deviation from their means, holding other variables at their mean values (binary variables are set to zero). ${ }^{15}$ I estimate these effects for members of each party using Model 4.3 and Model 4.4. The impact of ideology is substantively large and very precisely estimated for both Democrats and Republicans: a one standard deviation increase in DWNOMINATE above the party mean - a move to the right — reduces the likelihood of a Democratic legislator supporting the IMF by 24 percentage points. A similar move reduces the chance that a Republican legislator will support the IMF by 31 percentage points. The effect of being in the Senate is also large: a Democratic senator is 10 percentage points more likely than a Democratic representative to support the IMF, and a Republican senator is 17 percentage points more likely than a Republican representative to support the IMF. These effects are large, even in comparison with the effect of being in the same party as the president. Sharing the party affiliation of the president increases the likelihood of voting more funds to the IMF by 13 percentage points for Democrats and 5 percentage points for Republicans.

To further explore Hypothesis 2, I take advantage of a "natural experiment" derived from apportionment procedures that give certain senators and representatives identically sized and equally heterogeneous constituencies. ${ }^{16}$ Due to their small populations, some states are apportioned only one legislator to the lower house and these "representatives-at-large" are elected by the entire state. ${ }^{17}$ Since senators from these small states are elected by the same constituency, a comparison of the votes cast on the IMF by representatives-at-large and senators from the same states allows for a direct test of the argument that members of the Senate are more pro-IMF than members of the House due to their larger constituencies. If it is the size of constituencies that matters, then voting by representatives-at-large and senators from the same states should be similar, controlling for legislators' personal characteristics,

\footnotetext{
${ }^{14}$ As DW-NOMINATE is constructed solely from roll call data, it incorporates both member beliefs and the ideological positions of constituents that elect members into Congress. See Fleck and Kilby (2002).

${ }^{15}$ The simulations were performed with the "Clarify" software developed by Tomz et al. (1998).

${ }^{16}$ See Karol (2007) for an application of this experiment to trade policy voting.

${ }^{17}$ The number of states with a representative-at-large has changed over time due to population and migration shifts. For the votes in my sample, the states with a single representative include Alaska (19592009), Delaware (1945-2009), Hawaii (1959), Montana (1991-2009), Nevada (1945-1978), North Dakota (1970-2009), South Dakota (1980-2009), Vermont (1945-2009), and Wyoming (1945-2009).
} 
Table 3 Roll-call votes on IMF financing in the U.S. congress, 1944-2009

\begin{tabular}{|c|c|c|c|c|c|}
\hline Chamber & Bill or amendment & Congress & Vote date & $\begin{array}{l}\text { Roll- } \\
\text { call }\end{array}$ & Result \\
\hline House & $\begin{array}{l}\text { H.R. } 3314 \text { to provide for the participation } \\
\text { of the U.S. in the IMF and the IBRD }\end{array}$ & 79th & $\begin{array}{c}\text { June } 7, \\
1945\end{array}$ & \#47 & $\begin{array}{r}345- \\
18\end{array}$ \\
\hline Senate & $\begin{array}{l}\text { To pass H.R. } 3314 \text { and provide for U.S. } \\
\text { participation in IMF and IBRD }\end{array}$ & 79th & $\begin{array}{c}\text { July } 19, \\
1945\end{array}$ & \#61 & $61-16$ \\
\hline House & $\begin{array}{l}\text { H.R. } 4452 \text { to amend the Bretton Woods } \\
\text { Agreements Act, changing the amount } \\
\text { of the U.S. quota for the IMF }\end{array}$ & 86th & $\begin{array}{l}\text { March 25, } \\
1959\end{array}$ & $\# 13$ & $\begin{array}{r}315- \\
57\end{array}$ \\
\hline Senate & $\begin{array}{l}\text { To pass H.R. } 4452 \text { and increase the U.S. } \\
\text { subscription to the IMF and World Bank }\end{array}$ & 86th & $\begin{array}{l}\text { March 19, } \\
1959\end{array}$ & $\# 24$ & $73-10$ \\
\hline House & $\begin{array}{l}\text { H.R. } 10162 \text { Provides standby authority } \\
\text { for the U.S. to loan } \$ 2 \text { Billion to the IMF }\end{array}$ & 87 th & $\begin{array}{c}\text { April 2, } \\
1962\end{array}$ & \#138 & $\begin{array}{r}257- \\
94\end{array}$ \\
\hline House & $\begin{array}{l}\text { H.R. } 6497 \text { to authorize an increase } \\
\text { in the IMF quota of the U.S. }\end{array}$ & 89th & $\begin{array}{l}\text { April 27, } \\
1965\end{array}$ & $\# 40$ & $\begin{array}{r}301- \\
88\end{array}$ \\
\hline House & $\begin{array}{l}\text { H.R. } 18306 \text { to increase appropriations } \\
\text { for the IMF and IBRD }\end{array}$ & $91 \mathrm{st}$ & $\begin{array}{l}\text { Sept } 14, \\
1970\end{array}$ & \#344 & $\begin{array}{r}177- \\
140\end{array}$ \\
\hline House & $\begin{array}{l}\text { H.R. } 13955 \text { authorizing changes } \\
\text { in the U.S. quota and SDR. }\end{array}$ & 94th & $\begin{array}{c}\text { July } 27, \\
1976\end{array}$ & \#1028 & $\begin{array}{r}289- \\
121\end{array}$ \\
\hline House & $\begin{array}{l}\text { H.R. } 9214 \text { authorizing the U.S. to participate } \\
\text { in the Supplementary Financing Facility } \\
\text { of the IMF }\end{array}$ & 95th & $\begin{array}{c}\text { Feb 23, } \\
1978\end{array}$ & \#767 & $\begin{array}{r}267- \\
125\end{array}$ \\
\hline Senate & To pass H.R. 9214 on Witteven and the IMF & 95th & $\begin{array}{c}\text { July } 31 \\
1978\end{array}$ & \#907 & $69-16$ \\
\hline House & $\begin{array}{l}\text { H.R. } 7244 \text { authorizing an increase in } \\
\text { funds in the U.S. quota of the IMF }\end{array}$ & 96th & $\begin{array}{l}\text { Sept } 18 \\
1980\end{array}$ & \#1168 & $\begin{array}{r}199- \\
151\end{array}$ \\
\hline Senate & $\begin{array}{l}\text { S. } 2271 \text { authorizing an increase in } \\
\text { funds in the U.S. quota of the IMF }\end{array}$ & 96th & $\begin{array}{c}\text { June } 16, \\
1980\end{array}$ & \#719 & $55-25$ \\
\hline House & $\begin{array}{l}\text { H.Amdt. } 341 \text { to amend H.R. } 2957 \text { to strike } \\
\text { the language that increases U.S. participation }\end{array}$ & 98th & $\begin{array}{l}\text { August 3, } \\
1983\end{array}$ & \#341 & $\begin{array}{r}174- \\
249\end{array}$ \\
\hline
\end{tabular}
in the IMF General Arrangements to Borrow from $\$ 2$ billion to $\$ 4.25$ billion, and authorizes the Secretary to consent to an increase of the U.S. quota in the IMF (nay vote supports the IMF)

Senate SAmdt. 1320 to amend S. 695 to make the increase in the U.S. quota in the Fund and the increased participation of the U.S. in the General Arrangements to Borrow effective only through the fiscal year 1984 (nay vote supports the IMF)

Senate S.Amdt. 835 to amend S. 1435 to strike additional U.S. contributions to the IMF (nay vote supports the IMF)

House Motion to allow the House and Senate to pass identical spending bills, providing the IMF with $\$ 18$ billion for quota increase and to establish the New Arrangements to Borrow (NAB)

$\begin{array}{cccc}\text { 102nd } & \begin{array}{c}\text { July 25, } \\ 1991\end{array} & \# 149 & 31-65 \\ & & & \\ & & & \\ \text { 105th } & \begin{array}{c}\text { April 23, } \\ 1998\end{array} & \# 737 & 186- \\ & & 222\end{array}$
1983 
Table 3 (continued)

Chamber Bill or amendment

Congress Vote date Roll- Result call

\begin{tabular}{|c|c|c|c|c|c|}
\hline Senate & $\begin{array}{l}\text { S.Amdt. } 2100 \text { to S. } 1768 \text { to provide supplemental } \\
\text { appropriations for the IMF }\end{array}$ & 105th & $\begin{array}{l}\text { March 26, } \\
1998\end{array}$ & \#342 & $84-16$ \\
\hline Senate & $\begin{array}{l}\text { S.Amdt. } 1138 \text { to H.R. } 2346 \text { (Supplemental } \\
\text { Appropriations Act, 2009) to strike the } \\
\text { provisions relating to increased funding } \\
\text { for the IMF (nay vote supports the IMF) }\end{array}$ & 111th & $\begin{array}{c}\text { May 21, } \\
2009\end{array}$ & \#201 & $30-64$ \\
\hline
\end{tabular}

Bill and vote information obtained from the "Voteview" and the Library of Congress "Thomas" websites

since they have identical constituencies. But if there is some unmodeled reason other than constituency size that accounts for why senators support the IMF more than Representatives, then voting by senators and representatives-at-large will be significantly different.

Table 5 presents the results of this experiment. Model 6.1 is the baseline model. Model 6.2 adds REP-AT-LARGE and SENATE * REP-AT-LARGE, the interaction of the Senate dummy and the binary variable indicating whether a member is from a state with only one representative. The interaction term picks up the cases where senators and representatives have exactly the same constituencies - it is a formal test of the hypothesis that constituency size explains the Senate-House gap in support for the IMF. Notice that the SENATE point estimate is virtually identical across Models 6.1 and 6.2 while the estimate for the interaction term SENATE * REP-AT-LARGE is not significantly different than zero. ${ }^{18}$ This means we cannot reject Hypothesis 2: the Senate-House gap in support for the IMF is the same for representatives-at-large and other cases, ceteris paribus. Put another way, legislators serving in the Senate are no more pro-IMF than legislators in the House when they have identical constituencies.

Model 6.3 moves away from the experiment to assess whether senators' length of tenure affects their voting behavior. Controlling for tenure length is important because senators may be more supportive of the IMF because they serve longer terms than representatives, rather than because they have larger constituencies. I assess this alternative institutional argument via variation among senators with respect to TIME TO ELECTION. This variable measures the number of years between an IMF roll-call vote and a senator's next election. It ranges from 0 to 5 , with 0 indicating that a senator is up for reelection later in the same year as the roll-call vote, and 5 indicates that the senator has 5 years remaining until her next election. ${ }^{19}$ The evidence from Model 6.3 supports the "larger constituency" hypothesis: the point estimate for TIME TO ELECTION is

\footnotetext{
${ }^{18}$ Interpreting interaction terms in non-linear models is not straightforward. For example, the direction and significance of the effect may be different for different observations (Ai and Norton 2003). Using the inteff command in STATA, I calculated the interaction effect correctly (Norton et al. 2004). This revealed that the interaction term SENATE * REP-AT-LARGE is not statistically significant at any level but positive for all observations.

${ }^{19}$ Senators are divided into three classes for purposes of elections and every 2 years the members of one class - approximately one-third of the Senate-face election or reelection. Data on the class and election dates of senators are from Swift et al., Database of Congressional Historical Statistics.
} 
Table 4 Roll-call voting on IMF funding increases, 1944-2009

\begin{tabular}{llllll}
\hline & $(4.1)$ & $(4.2)$ & $(4.3)$ & $(4.4)$ & $(4.5)$ \\
& Democrats & Republicans & Democrats & Republicans & All \\
\hline DW-NOMINATE & -3.288 & -4.547 & -3.274 & -4.708 & -2.529 \\
& $(0.247)^{* * *}$ & $(0.305)^{* * *}$ & $(0.247)^{* * *}$ & $(0.322)^{* * *}$ & $(0.109)^{* * *}$ \\
President's Party & 0.521 & 0.117 & 0.523 & 0.112 & 0.387 \\
& $(0.058)^{* * *}$ & $(0.061)^{*}$ & $(0.058)^{* * *}$ & $(0.062)^{*}$ & $(0.044)^{* * *}$ \\
Senate & & & 0.362 & 0.429 & 1.102 \\
& & & $(0.134)^{* * *}$ & $(0.109)^{* * *}$ & $(0.178)^{* * *}$ \\
Constant & -0.171 & 1.291 & -0.215 & 1.264 & -0.129 \\
Vote fixed effects & $(0.072)^{* *}$ & $(0.107)^{* * *}$ & $(0.075)^{* * *}$ & $(0.109)^{* * *}$ & $(0.081)$ \\
Pseudo R & No & No & No & No & Yes \\
Number of groups & 0.198 & 0.223 & 0.203 & 0.232 & 0.322 \\
Observations & 1189 & 910 & 1189 & 910 & 2100 \\
\hline
\end{tabular}

Probit regressions with robust standard errors clustered by group (legislator) in parentheses. The omitted roll-call vote in Model 5 is S1945. *** $p<0.01, * * p<0.05, * p<0.1$

positive but not statistically significant. For senators, the length of time between elections is not statistically related to voting on the IMF, which supports the hypothesis that the Senate-House difference in support for the IMF is due to constituency differences.

Overall, the inference is that constituency differences are the root cause of the pro-IMF bias in the Senate. In states where representatives and senators share the same constituency, they tend to vote similarly on IMF funding. In all other states, senators have larger and more diverse constituencies than representatives and are more supportive of the IMF because of the difference in constituency size.

My third hypothesis is that representatives are more susceptible than senators to interest group and constituency pressures. I argue that the IMF tends to provoke two types of societal pressures that bear especially on representatives (due to their smaller districts): pressures from groups that are harmed or benefited from globalization-which the IMF promotes-and pressures and rewards from money center banks that gain directly from IMF activities. I proxy legislator affinity to money center banks by the amount of campaign contributions members receive from these banks. To identify money center banks, I use the regulatory classification in the Federal Financial Institutions Examination Council's (FFIEC) "Country Exposure Lending Survey." Because the FFIEC identifies the specific banks that comprise the money center group, I was able to obtain a list on which to base the collection of campaign contribution data (see the Data Appendix for the banks that make up this group). For campaign contributions, I use the Federal Election Commission's data on contributions from Political Action Committees (PACs). My constructed variable is BANK CONTRIBUTIONS: the sum total of money center bank contributions to each legislator 


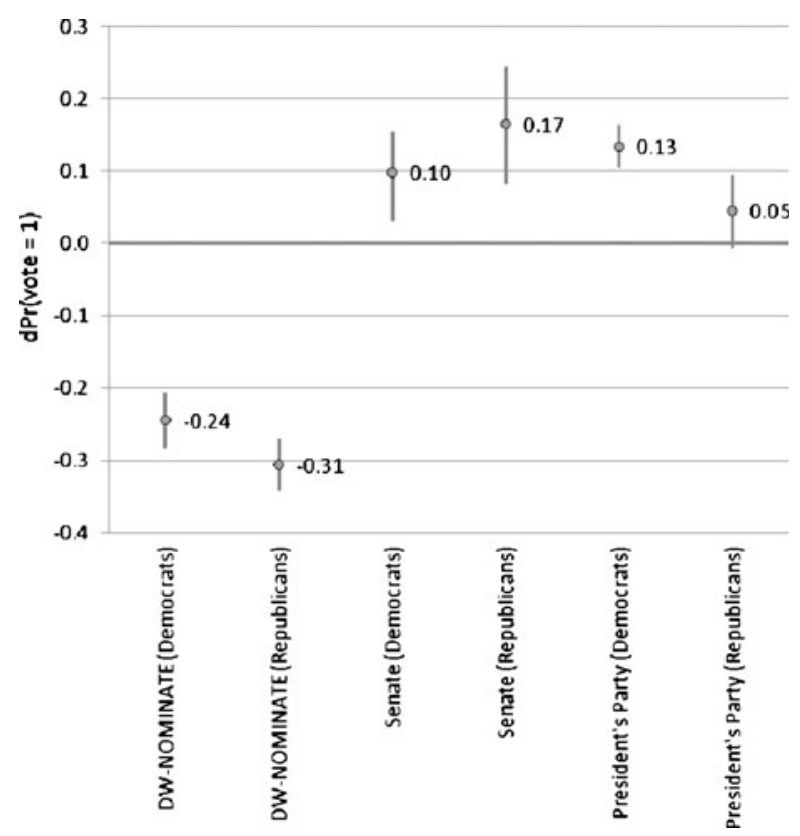

Fig. 4 Substantive effects of legislator ideology, chamber, and political party on support for the IMF. Notes: Values represent the change in the predicted probability of voting in favor of IMF funding as each variable of interest is increased by one standard deviation over its mean, holding other variables at their means (binary variables Senate and President's Party are held at zero). Estimates are from Models 4.3 and 4.4. The whiskers indicate $95 \%$ confidence intervals

in the previous electoral cycle. The value of contributions is divided by 1,000 for ease of interpretation.

I also expect representatives to be sensitive to the indirect effects of globalization on their districts: the larger the share of voters in a district that benefit (lose) from global economic integration, the more likely a member will be to support (oppose) the IMF. The winners (losers) can be defined by industry, following Ricardo-Viner reasoning, or by skill level following Stolper-Samuelson. Either operationalization captures my argument that legislators understand that the IMF promotes globalization, and take positions that reflect the impact of globalization on the real incomes of their constituents.

My proxies for the Ricardo-Viner effect are NET IMPORTS and NET EXPORTS. NET IMPORTS is the percentage of district workers employed in manufacturing industries where the ratio of imports to consumption is greater that the ratio of revenues from exports to total industry revenue. NET EXPORTS is the percentage of workers in sectors where the ratio of revenues from exports to total industry revenue is greater than the ratio of imports to consumption (see the Data Appendix for more details). To tap agricultural trade, I use AG PRODUCTION, which is the total value of agricultural output (crops and

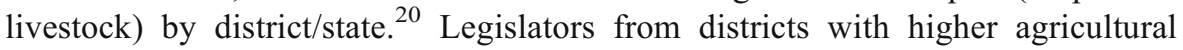

\footnotetext{
${ }^{20}$ I thank Dustin Tingley and Helen Milner for these agricultural data, which they constructed from countylevel U.S. Department of Agriculture data. See Milner and Tingley (2010).
} 
Table 5 "Natural experiment" comparison of senators and representatives-at-large with identical constituencies

\begin{tabular}{llll}
\hline & $(6.1)$ & $(6.2)$ & $\begin{array}{l}(6.3) \\
\text { Senators Only }\end{array}$ \\
\hline DW-Nominate & -2.203 & -2.202 & -1.982 \\
& $(0.093)^{* * *}$ & $(0.093)^{* * *}$ & $(0.234)^{* * *}$ \\
President's Party & 0.281 & 0.281 & 0.237 \\
& $(0.039)^{* * *}$ & $(0.039)^{* * *}$ & $(0.112)^{* *}$ \\
Senate & 0.359 & 0.357 & \\
& $(0.08)^{* * *}$ & $(0.086)^{* * *}$ & \\
Rep-At-Large & & -0.079 & \\
& & $(0.288)$ & \\
Senate * Rep-At-Large & & 0.083 & \\
& & $(0.344)$ & 0.040 \\
Time to Election & & & $(0.034)$ \\
Constant & & 0.327 & 0.576 \\
Vote Fixed Effects & 0.326 & $(0.037)^{* * *}$ & $(0.128)^{* * *}$ \\
Pseudo R & $(0.037)^{* * *}$ & No & No \\
Number of Groups & No & 0.221 & 0.222 \\
Observations & 0.221 & 2100 & 386 \\
\hline
\end{tabular}

Probit regressions with robust standard errors clustered by group (legislator) in parentheses. Including vote fixed effects (not shown) does not substantively alter these results. ${ }^{* *} p<0.01,{ }^{* *} p<0.05,{ }^{*} p<0.1$

output should be more supportive of the IMF since those districts are likely to be net exporters of farm products. To model Stolper-Samuelson effects, in which I posit a positive relationship between constituent skill levels and legislator support for the IFIs, I use HIGH SKILLS, which is the share of state or district population aged 16 and above employed in executive, administrative, managerial, and professional specialty occupations. However, since high skills might correlate with wealth or education which could lead constituents to favor the IMF, I include a control of district/state household MEDIAN INCOME.

Due to data availability limitations, I can only test these pressure group models back to 1980 for the House and 1991 for the Senate. Table 6 presents estimates with votes pooled by chamber. The results largely confirm the inference that representatives will be more susceptible to interest group and constituency pressures than senators. In Model 7.1 (House votes) and Model 7.3 (Senate votes), I do not control for DW-NOMINATE and PRESIDENT'S PARTY. This is because member ideology and party affiliation are, to some extent, indirect reflections of constituency interests: voters elect legislators whose ideology and political party suggest they will vote in accordance with constituents' interests (Fleck and Kilby 2002; Fordham and McKeown 2003). To the extent that legislator ideology and partisanship influence voting in a way that is not determined by constituency interests via elections, those elements of DW-NOMINATE and PRESIDENT'S PARTY are uncorrelated with 
constituency interests and omitting them won't cause omitted variable bias. ${ }^{21}$ The coefficients on my other constituency variables will thus reflect the full influence of constituents: both electing and lobbying legislators. Nevertheless, in Models 7.2 and 7.4, I include DW-NOMINATE and PRESIDENT'S PARTY as controls for comparison. In these models, the direct (lobbying) and indirect (electing) channels through which constituents influence legislator voting are included, but it is impossible to attribute indirect influence properly.

Comparing across Models 7.1 and 7.3 provides evidence that the House and Senate differ in terms of sensitivity to societal pressures. In Model 7.1 (House votes), all constituency and special interest coefficients are statistically significant and correctly signed, with the exception of AG PRODUCTION, which is significant but negatively signed. Farm interests should support the IMF since a large share of the agricultural land in the United States is devoted to grain production for export markets and the IMF's mission is to promote trade. The negative estimate may be due to the fact that AG PRODUCTION is correlated with legislator ideology: farming regions in the U.S. tend to elect legislators. Indeed, in Model 7.2, which controls for ideology with DW-NOMINATE, the sign flips and AG PRODUCTION is positively signed, as expected, and significant.

All other point estimates in Model 7.1 support Hypothesis 3. Receiving more campaign contributions from money center banks (BANK CONTRIBUTIONS), and having more skilled workers a district (SKILLS), correlate positively and significantly with a House member voting in support of the IMF. ${ }^{22}$ Members representing districts with larger shares of workers employed in import industries (NET IMPORTS) are less likely to vote new funding for the IMF, while members with more workers in net export industries (NET EXPORTS) are more likely to support the IMF. ${ }^{23}$ As a group, the first five (constituency) variables in Model 7.1 are jointly significant at the 0.0001 level. Model 7.2, which controls for legislator ideology and partisanship, does little to alter the inference that voting in the House on the IMF is correlated with constituent characteristics and interest group pressures. The joint significance of the five constituency variables in Model 2 is very highly significant $(P=0.0000)$. By contrast, none of these coefficient estimates are significant, either independently or jointly, in Model 7.3 or Model 7.4, which pool votes from the Senate. While House members are sensitive to constituency influences, senators appear to be insulated from these forces.

As a final test, I consider whether heterogeneity within states bears on IMF voting in the Senate. ${ }^{24}$ Bailey and Brady (1998) argue that constituent pressures are more likely to influence the votes of senators when states are relatively homogenous in terms of voter preferences. The intuition is that homogeneity of voter preferences simplifies legislators' electoral coalition-building problem sufficiently that they take positions on salient issues that are responsive to voter

\footnotetext{
${ }^{21}$ I thank Christopher Kilby for this suggestion.

22 This does not necessarily indicate that bank contributions cause members to change their votes. The positive correlation might simply mean that banks give money to representatives that share their policy views.

23 Testing both Stolper-Samuelson and Ricardo Viner effects in the same model may not be technically correct (Imai and Tingley 2011; Ladewig 2006), but I do so here to ease comparison with previous work.

${ }^{24}$ I thank a reviewer for suggesting this test.
} 
Table 6 Constituency and special interest group influences, by chamber

\begin{tabular}{|c|c|c|c|c|c|}
\hline & $(7.1)$ & $(7.2)$ & $(7.3)$ & $(7.4)$ & $(7.5)$ \\
\hline & $\begin{array}{l}\text { House } 1980 \text {, } \\
1983,1998\end{array}$ & $\begin{array}{l}\text { House } 1980 \text {, } \\
1983,1998\end{array}$ & $\begin{array}{l}\text { Senate 1991, } \\
1998,2009\end{array}$ & $\begin{array}{l}\text { Senate 1991, } \\
1998,2009\end{array}$ & $\begin{array}{l}\text { Senate Homogeneous } \\
\text { States Only }\end{array}$ \\
\hline Bank contributions & $\begin{array}{l}0.017 \\
(0.009)^{* *}\end{array}$ & $\begin{array}{l}0.037 \\
(0.010)^{* * *}\end{array}$ & $\begin{array}{l}-0.004 \\
(0.009)\end{array}$ & $\begin{array}{l}0.005 \\
(0.009)\end{array}$ & $\begin{array}{l}-0.005 \\
(0.011)\end{array}$ \\
\hline Skill level & $\begin{array}{l}1.097 \\
(0.631)^{*}\end{array}$ & $\begin{array}{l}2.239 \\
(0.742) * * *\end{array}$ & $\begin{array}{l}2.278 \\
(3.245)\end{array}$ & $\begin{array}{l}0.398 \\
(3.083)\end{array}$ & $\begin{array}{l}23.191 \\
(14.857)\end{array}$ \\
\hline Net imports & $\begin{array}{l}-0.975 \\
(0.555)^{*}\end{array}$ & $\begin{array}{l}0.241 \\
(0.669)\end{array}$ & $\begin{array}{l}-1.837 \\
(2.289)\end{array}$ & $\begin{array}{l}-1.766 \\
(2.608)\end{array}$ & $\begin{array}{l}0.042 \\
(4.688)\end{array}$ \\
\hline Net exports & $\begin{array}{l}2.997 \\
(1.145) * * *\end{array}$ & $\begin{array}{l}3.547 \\
(1.736)^{* *}\end{array}$ & $\begin{array}{l}-3.040 \\
(4.919)\end{array}$ & $\begin{array}{l}-6.450 \\
(4.889)\end{array}$ & $\begin{array}{l}-7.634 \\
(9.373)\end{array}$ \\
\hline $\mathrm{Ag}$ production & $\begin{array}{l}-21.188 \\
(6.816)^{* * *}\end{array}$ & $\begin{array}{l}11.439 \\
(6.038)^{*}\end{array}$ & $\begin{array}{l}-8.762 \\
(13.647)\end{array}$ & $\begin{array}{l}-20.645 \\
(12.926)\end{array}$ & $\begin{array}{l}-26.552 \\
(24.063)\end{array}$ \\
\hline Median income & $\begin{array}{l}-0.001 \\
(0.008)\end{array}$ & $\begin{array}{l}0.026 \\
(0.009)^{* * *}\end{array}$ & $\begin{array}{l}0.056 \\
(0.024)^{* *}\end{array}$ & $\begin{array}{l}0.017 \\
(0.024)\end{array}$ & $\begin{array}{l}-0.070 \\
(0.051)\end{array}$ \\
\hline H1983 & $\begin{array}{l}-0.075 \\
(0.113)\end{array}$ & $\begin{array}{l}-0.087 \\
(0.136)\end{array}$ & - & - & - \\
\hline H1998 & $\begin{array}{l}-0.327 \\
(0.261)\end{array}$ & $\begin{array}{l}-0.540 \\
(0.307)^{*}\end{array}$ & - & - & - \\
\hline DW-Nominate & - & $\begin{array}{l}-2.643 \\
(0.160)^{* * *}\end{array}$ & - & $\begin{array}{l}-1.875 \\
(0.400)^{* * *}\end{array}$ & $\begin{array}{l}-3.360 \\
(0.908)^{* * *}\end{array}$ \\
\hline President's Party & - & $\begin{array}{l}0.452 \\
(0.084)^{* * *}\end{array}$ & $\begin{array}{l}- \\
-\end{array}$ & $\begin{array}{l}0.421 \\
(0.259)\end{array}$ & $\begin{array}{l}1.142 \\
(0.677)^{*}\end{array}$ \\
\hline S1998 & - & - & $\begin{array}{l}1.103 \\
(0.287)^{* * *}\end{array}$ & $\begin{array}{l}1.257 \\
(0.431)^{* * *}\end{array}$ & $\begin{array}{l}1.629 \\
(0.884)^{*}\end{array}$ \\
\hline S2009 & $\begin{array}{l}- \\
-\end{array}$ & - & $\begin{array}{l}-0.089 \\
(0.221)\end{array}$ & $\begin{array}{l}0.207 \\
(0.252)\end{array}$ & $\begin{array}{l}1.005 \\
(0.755)\end{array}$ \\
\hline Constant & $\begin{array}{l}-0.055 \\
(0.273)\end{array}$ & $\begin{array}{l}-1.649 \\
(0.320)^{* * *}\end{array}$ & $\begin{array}{l}-1.741 \\
(1.037)^{*}\end{array}$ & $\begin{array}{l}0.138 \\
(1.112)\end{array}$ & $\begin{array}{l}-2.266 \\
(3.529)\end{array}$ \\
\hline Pseudo R2 & 0.036 & 0.351 & 0.103 & 0.315 & 0.419 \\
\hline Number of groups & 836 & 836 & 191 & 190 & 92 \\
\hline Observations & 1150 & 1150 & 289 & 288 & 126 \\
\hline
\end{tabular}

Probit regressions with robust standard errors clustered by group (legislator) in parentheses. The omitted category in Model 7.2 is H1980. The omitted category in Models 7.4 and 7.5 is S1991. ${ }^{* * *} p<0.01,{ }^{* *} p<0.05,{ }^{*} p<0.1$

preferences. By contrast, when voter preferences within a state are heterogeneous, senators are less responsive to constituents and more apt to vote on the basis of ideology and party-specific coalitions. Since this is a very different mechanism than the one I posit, I need to confirm that the Senate is less responsive to constituency interests due to senators' larger districts. To do so, I re-estimate Model 7.5 on a sample restricted to the 25 states that Bailey and Brady (1998) 
determine to be homogenous. ${ }^{25}$ As none of the constituency and interest group point estimates are statistically significant in this sample, we can reject the alternative hypothesis that the mechanism insulating senators from constituency pressures is the underlying homogeneity of states.

Figure 5 plots the substantive effects of constituency and interest group effects by chamber from Models 7.1 and 7.3. For the House, my estimates suggest that a one standard deviation increase in BANK CONTRIBUTIONS above its mean increases the likelihood that a representative will support the IMF by 4 percentage points. ${ }^{26}$ The same effect holds for House members when SKILL LEVEL and NET EXPORTS are increased by a standard deviation, but the later is more precisely estimated. Increasing the share of House district employment in the NET IMPORT sector reduces the likelihood that a representative will support the IMF by 3 percentage points. But in the Senate, the effects of changing BANK CONTRIBUTIONS, SKILL LEVEL, NET EXPORTS, and NET IMPORTS are never statistically different than zero. Overall, representatives appear to be more responsive to constituent interests and pressure group lobbying than senators.

\section{Conclusion}

When Congress ratified United States participation in the IMF in 1944, it retained permanent authority over increases in U.S. financial commitments to this international organization. I have analyzed roll-call voting on IMF funding increases as if it is a historical record of "support" for the IMF within the United States. I found that support for the IMF is generally higher in the Senate than in the House due to differences in electoral rules between the chambers. Large districts - as opposed to long tenures - appear to make the Senate the more "internationalist" chamber on IMF policy and insulate senators from constituent and interest group pressures. I also found that ideology is an important source of congressional voting decisions on the IMF, with right-leaning legislators more likely to vote against new IMF funding than left-wing legislators. While politicians on the right tend to view the IMF as a profligate bureaucracy that distorts incentives in international financial markets, left-wing legislators view the IMF more favorably because they think international financial markets are prone to crises and need a crisis manager. ${ }^{27}$

\footnotetext{
${ }^{25}$ Bailey and Brady (1998) construct an index of state heterogeneity from six social, economic, and religious variables: education, income, occupation, housing ownership, ethnic stock, and religion. Using this index, they rank states from the most to the least heterogeneous: NY, NJ, MA, CA, CT, HI, RI, IL, LA, FL, NM, PA, WI, NH, TX, VT, ND, AZ, MD, MI, MN, DE, NV, OH, CO, ME, WA, NE, MO, AK, SD, MT, OR, IA, KS, VA, IN, WY, KY, GA, ID, UT, OK, MS, AL, SC, TN, WV, NC, AR. The 25 states ranked below Colorado are coded as "homogeneous."

${ }^{26}$ Endogeneity is a concern here as banks may give contributions to representatives that already share their policy positions rather than to "buy their votes." However, Broz (2008) performs a difference-indifference test to establish that causality runs from bank contributions to IMF voting, as opposed to the other way around.

${ }^{27}$ To quote right-wing conservative Newt Gingrich, the 1998 IMF quota increase was "typical liberal foreign policy... we're not turning over $\$ 18$ billion to a French Socialist [Michel Camdessus] to throw it away." Camdessus was Managing Director of the IMF at the time. Speech before the Christian Coalition, September 18, 1998, Washington, DC. Cited in the New York Times, September 25, 1998.
} 


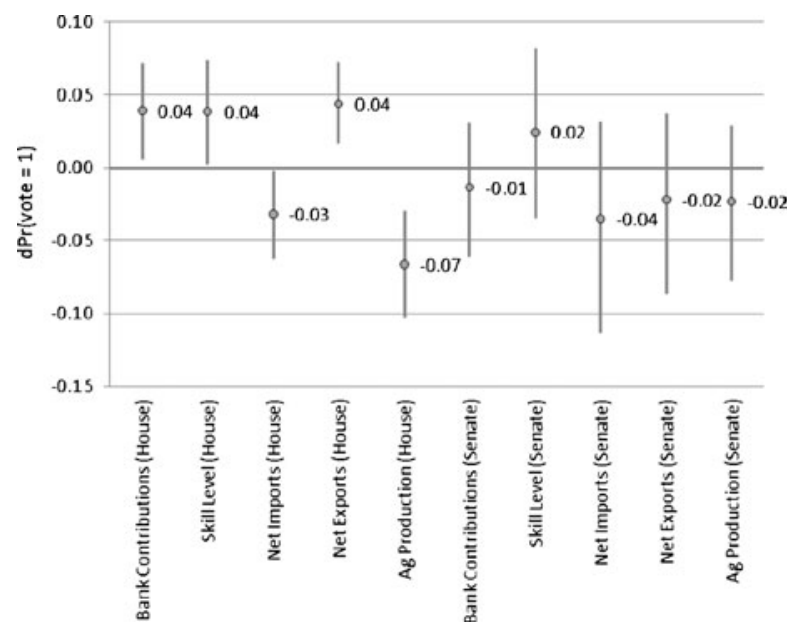

Fig. 5 Substantive effects of constituency pressures in the house and senate. Notes: Values represent the change in the predicted probability of voting in favor of IMF funding as each variable of interest is increased by one standard deviation over its mean, holding other variables at their means (or zero for binary variables). Estimates are from Model 7.1 (House) and Model 7.3 (Senate). The whiskers indicate $95 \%$ confidence intervals

An implication of both findings is that an aggregate shift to the right in U.S. politics poses significant problems for the IMF and its supporters, especially in the House of Representatives. Since the early 1990s, the House has moved substantially to the right and this has led IMF supporters to innovate strategies to secure approval of new funding. One strategy has been to package IMF funding with other spending projects that right-wing legislators are loathe to oppose (Babb 2009). But there are limits to the effectiveness of this approach: opponents on the right can try to build majorities for amendments to strip the IMF allocation from these engineered bills. They can also call the bluff and vote against the strategically constructed bill, albeit at a cost.

A case in point occurred when President Obama was trying to get approval for the $\$ 100$ billion line of credit to the IMF to meet the commitment he made at the April 2009 meeting of the G20. Supporters in the Senate attached the IMF money to a supplemental war spending bill after the House had already passed its war spending bill without IMF funds. Since normal procedure is for the two chambers to reconcile their differences and present an identical bill, the plan was to conjoin IMF funding with "funding the troops" so that right-wing House members would be more inclined to support it.

The strategy faced its first hurdle when House Republicans, who had supplied 168 votes for the war spending in the House, said they would vote against the war supplemental en masse unless the IMF money was put to a separate vote. But the joint IMF-war supplemental bill moved forward after the Senate voted overwhelming against an amendment to strike the IMF allocation; as I have shown, the Senate is a safe haven for the IMF. As the bill moved forward, the White House and the Democratic leadership, lead by House Speaker Nancy Pelosi (D-CA), went into high gear 
threatening and offering deals to 51 anti-war Democrats that had opposed the war funds the first time around. The pressure worked and the bill squeaked through by a vote of 226-208, with 32 Democrats joining all but five Republicans in voting no. Throughout the drama, there were serious doubts that the strategy would work (Allen 2009).

It is no surprise that the House is the locus of anti-IMF sentiment in the United States. I have shown that institutional factors help explain why IMF support varies by chamber, with the Senate substantially more supportive than the House. Due to their large, state-wide constituencies, senators are more apt to support the IMF's "internationalism," even as increasing globalization brings dislocations to some workers and industries and benefits to others.

Open Access This article is distributed under the terms of the Creative Commons Attribution Noncommercial License which permits any noncommercial use, distribution, and reproduction in any medium, provided the original author(s) and source are credited.

\section{Data Appendix}

AG PRODUCTION: Market value of agricultural products (livestock and crops) taken from county level data collected by the 1978, 1982, 1987, 1992, 1997 and 2002 Census of Agriculture. Converted into 2000 constant dollars and divided by 10,000. Source: Milner and Tingley (2010).

BANK PAC: Campaign contributions from money center bank political action committees to candidates in the previous electoral cycle, divided by 1,000 (contemporaneous 1979-80 data were used HR 7244). Money center banks are identified by the Federal Financial Institutions Examination Council, Country Exposure Lending Survey (various years). In the 1979-80 cycle, the FFIEC list includes Bankers Trust, Chase Manhattan, Chemical Bank, Citicorp, Continental Illinois, First Chicago, Manufacturers Hanover, and J.P. Morgan \& Co. In the 198182 cycle, BankAmerica Corp joins the list. By the 1996-97 cycle, consolidations and takeovers reduced the list of money center banks to Bank of America, Bankers Trust, Chase Manhattan, Citicorp, First Chicago, and J. P. Morgan \& Co). In the 2007-08 cycle, the banks were Bank of America, Citigroup, J. P. Morgan Chase, U.S. Bancorp, Wachovia, and Wells Fargo. Contributions from these banks' political action committee to candidates are from the Federal Election Commission.

DW-NOMINATE: The first dimension of the DW-Nominate score, capturing a member's ideological position on government intervention in the economy. DWNominate estimates the position of each legislator, using roll call voting and scaling techniques. Scores range from -1 to 1 , with higher values denoting a more rightwing ideology. McCarty, Poole, and Rosenthal (1997).

INTERNATIONAL CRISIS: Denotes whether a major international financial crisis occurred during the year of the roll-call vote, where $1=$ crisis, 0 no crisis. Crisis roll calls are: \#341 (H1983), \#125 (S1983), \#737 (H1998), \#342 (H1998), and \#201 (S2009). 
MEDIAN INCOME: Median district household income, divided by 1,000. Source: Adler, E. Scott. "Congressional District Data File, [congressional term]." University of Colorado, Boulder, CO.

NET EXPORTS: Percent district population aged 16 years and over employed in net export industries. Net export industries are two-digit SIC manufacturing sectors where the ratio of revenues from exports to total industry revenue is greater than the ratio of imports to consumption. These ratios are provided by Campa and Goldberg (1997) for three time periods: 1975, 1985, 1995. I used the sample closest to each vote to assemble the data. In 1975, net export industries were Tobacco 21, Textiles 22, Lumber 24, Printing 27, Chemicals 28, Fabricated metals 34, Industrial machinery 35, Electronic equipment 36, Transportation equipment 37, and Instruments 38. In 1985, net export industries were Tobacco 21, Chemicals 28, Industrial machinery 35, and Instruments 38. In 1995, net export industries were Food 20, Tobacco 21, Printing 27, Chemicals 28, and Instruments 38. The source for sectoral employment is the County Business Patterns, Bureau of the Census. County-level employment data was aggregated up to the congressional district level using the following procedure: If a county contains more than one congressional district within its borders, the number of workers from an industry who are in each district is estimated by using the fraction of the county's population residing in each district. For example, if $10 \%$ of a county's population lives in a district, that district receives 10 percent of the county's workers in each industry. I obtained the geographic information from the MABLE '98/Geocorr v3.0 Geographic Correspondence Engine [http://plue.sedac. ciesin.org/plue/geocorr].

NET IMPORTS: Percent district population aged 16 years and over employed in net import industries. Net import industries are two-digit SIC manufacturing sectors where the ratio of imports to consumption is greater than the ratio of revenues from exports to total industry revenue. These ratios are provided by Campa and Goldberg (1997) for three time periods $1975,1985,1995$. I used the sample closest to each vote. In 1975, net import industries were Food 20, Apparel 23, Furniture 25, Petroleum 29, Rubber 30, Leather 31, Primary metals 33, and Other manufacturing 39. In 1985, net import industries were Food 20, Textiles 22, Apparel 23, Lumber 24, Furniture 25, Paper 26, Petroleum 29, Rubber 30, Leather 31, Stone, Clay and Glass 32, Primary metals 33, Fabricated metals 34, Electronic goods 36, Transportation equipment 37, and Other manufacturing 39. In 1995, net import industries were Textiles 22, Apparel 23, Lumber 24, Furniture 25, Paper 26, Petroleum 29, Rubber 30, Leather 31, Stone, Clay and Glass 32, Primary metals 33, Fabricated metals 34, Industrial Machinery 35, Electronic goods 36, Transportation equipment 37, Instruments 38, and Other manufacturing 39. Sectoral employment is from County Business Patterns, Bureau of the Census. See "Net Imports" for the concordance procedure.

PRESIDENT'S PARTY: Denotes whether a member is of the same political party as the current president, where, $1=$ same party, 0 otherwise.

TIME TO ELECTION: Denotes the number of years between an IMF roll-call vote and a legislator's next election. For senators, this variable ranges from 0 to 5 , with 0 indicating that the Senator is up for reelection later in the same year as the 
roll-call vote, and 5 indicating that the Senator was has 5 years remaining until his/ her next election.

\section{References}

Ai, C., \& Norton, E. C. (2003). Interaction terms in logit and probit models. Economic Letters, 80, 123129.

Allen, J. (2009). "Pelosi’s War Bill Pitch Gets Personal.” CQ Politics News (June 10). http://www. cqpolitics.com/wmspage.cfm?docID=news-000003140209.

Babb, S. (2009). Behind the development banks: Washington politics, world poverty, and the wealth of nations. University of Chicago Press.

Bailey, M. A., \& Brady, D. W. (1998). Heterogeneity and representation: the senate and free trade. American Journal of Political Science, 42(2), 524-544.

Bailey, M. A., Goldstein, J., \& Weingast, B. A. (1997). The institutional roots of American trade policy: politics, coalitions and international trade. World Politics, 49(3), 309-338.

Baldwin, R. E. (1985). The political economy of U.S. import policy. Cambridge: MIT Press.

Bird, G. (1996). The International Monetary Fund and developing countries: a review of the evidence and policy options. International Organization, 50, 477-511.

Bordo, M. D., \& James, H. (2000). The International Monetary Fund: its present role in historical perspective. NBER Working Paper 7724 (June): 1-57.

Boughton, J. M. (2001). Silent revolution: The International Monetary Fund, 1979-1989. Washington: International Monetary Fund.

Broz, J. L. (2008). Congressional voting on funding the international financial institutions. The Review of International Organizations, 3(4), 351-337.

Broz, J. L., \& Hawes, M. B. (2006a). Congressional politics of financing the International Monetary Fund. International Organization, 60(1), 367-399.

Broz, J. L., \& Hawes, M. B. (2006b). U.S. domestic politics and International Monetary Fund policy. In D. Hawkins, D. A. Lake, D. Nielson, \& M. J. Tierney (Eds.), Delegation and agency in international organizations. Cambridge University Press.

Bulow, J., \& Rogoff, K. (1990). Cleaning up third-world debt without getting taken to the cleaners. The Journal of Economic Perspectives, 4, 31-42.

Campa, J., \& Goldberg, L. S. (1997). The evolving external orientation of manufacturing industries: a profile of four countries. The Federal Reserve Bank of New York Economic Policy Review, 53-81.

Cronin, P., \& Fordham, B. (1999). Timeless principles or today's fashion? Testing the stability of the linkage between ideology and foreign policy in the Senate. Journal of Politics, 4, 967-998.

Davis, B., \& Hitt, G. (2009). Congress hesitant on IMF funding. Wall Street Journal, June 11: A10.

Demirguc-Kunt, A., \& Huizinga, H. (1993). Official credits to developing countries: implicit transfers to the banks. Journal of Money, Credit and Banking, 25(3), 430-444.

Destler, I. M. (2005). American trade politics, 4th Edn. Institute for International Economics.

Farnsworth, C. H. (1983). Reagan praises I.M.F and warns Congress over delay in new aid. The New York Times, (September 28), 1.

Fleck, R. K., \& Kilby, C. (2002). Reassessing the role of constituency in congressional voting. Public Choice, 112(1/2), 31-53.

Fordham, B. O., \& McKeown, T. J. (2003). Selection and influence: interest groups and congressional voting on trade policy. International Organization, 57(3), 519-549.

Frankel, J., \& Roubini, N. (2003). The role of industrial country policies in emerging market crises. In M. Feldstein (Ed.), Economic and financial crises in emerging market economies (pp. 155-246). The University of Chicago Press.

Gilligan, M. J. (1997). Empowering exporters: Reciprocity, delegation and collective action in American trade policy. Ann Arbor: University of Michigan Press.

Gould, E. R. (2003). Money talks: supplementary financiers and International Monetary Fund conditionality. International Organization, 57(3), 551-586.

Historical Statistics of the United States: Millennial Edition Online. (2010). Cambridge University Press. Imai, K., \& Tingley, D. (2011). A statistical method for empirical testing of competing theories. Working Paper. 
Irwin, D. A., \& Kroszner, R. S. (1999). Interests, institutions and ideology in securing policy change: the Republican conversion to trade liberalization after Smoot-Hawley. Journal of Law and Economics, 42 (2), 643-673.

Karol, D. (2007). Does constituency size affect elected officials' trade policy preferences? The Journal of Politics, 69(2), 483-494.

Keech, W., \& Pak, K. (1995). Partisanship, institutions and change in American trade politics. The Journal of Politics, 57(4), 1130-1142.

Ladewig, J. W. (2006). Domestic influences on international trade policy: factor mobility in the United States, 1963 to 1992. International Organization, 60(1), 69-103.

Locke, M. (2000). Funding the IMF: the debate in the U.S. Congress. Finance and Development, 37, 3.

Lohmann, S., \& O'Halloran, S. (1994). Divided government and U.S. trade policy: theory and evidence. International Organization, 48(4), 595-632.

Magee, S. P., Brock, W. A., \& Young, L. (1989). Black hole tariffs and endogenous policy theory: Political economy in general equilibrium. New York: Cambridge University Press.

Meernik, J., \& Oldmixon, E. (2004). Internationalism in Congress. Political Research Quarterly, 57(3), 451-465.

Meltzer, A. H. (1998). Asian problems and the IMF. Cato Journal, 17(3), 267-274.

Meltzer, A. H. (2011). The IMF returns. Review of International Organizations 6. Forthcoming.

Milner, H. V., \& Rosendorff, B. P. (1996). Trade negotiations, information and domestic politics: the role of domestic groups. Economics and Politics, 8(2), 145-189.

Milner, H. V., \& Tingley, D. (2010). Who supports global economic engagement? The sources of preferences in American foreign economic policy. International Organization, forthcoming.

Moser, C., \& Strum, J.-E. (2011). Explaining IMF Lending Decisions after the Cold War. Review of International Organizations 6. Forthcoming.

Norton, E. C., Wang, H., \& Ai, C. (2004). Computing interaction effects and standard errors in logit and probit models. The Stata Journal, 4(2), 103-116.

Oatley, T., \& Yackee, J. (2004). American interests and IMF lending. International Politics, 41(3), 415429.

Poole, K. T. (2005). Spatial models of parliamentary voting. Cambridge: Cambridge University Press.

Poole, K. T., \& Rosenthal, H. (1997). Congress: A political-economic history of roll call voting. New York: Oxford University Press.

Poole, K. T., \& Rosenthal, H. (2007). Ideology and Congress. New Brunswick: Transaction Publishers.

Rogoff, K. (1999). International institutions for reducing global financial instability. The Journal of Economic Perspectives, 13(4), 21-42.

Rogowski, R. (1987). Trade and the variety of democratic institutions. International Organization, 41(2), 203-223.

Sanford, J. E., \& Weiss, M. A. (2009). The global financial crisis: Increasing IMF resources and the role of Congress. Report No. R40578. Congressional Research Service. Washington, DC (June 5): 1-26.

Smith, F. L., Jr. (1984). The politics of IMF lending. Cato Journal, 4, 211-241.

Snyder, J. M., Jr., \& Groseclose, T. (2000). Estimating party influence in congressional roll-call voting. American Journal of Political Science, 44(2), 193-211.

Tomz, M., Wittenberg, J., \& King, G. (1998). CLARIFY: Software for interpreting and presenting statistical results. Cambridge: Harvard University.

Woods, N. (2006). The globalizers: The IMF, the World Bank and their borrowers. New York: Cornell University Press. 